\title{
FEATURES OF THE DEVELOPMENT OF THE HEALTH INSURANCE SYSTEM IN THE WORLD
}

\author{
Umurzakova Mutabarkhan Nodir qizi \\ National University of Uzbekistan named after Mirza Ulugbeka faculty \\ «Economical» senior lecturer of the department «Macroeconomics»
}

\begin{abstract}
This article analyzes the strengths and weaknesses of the existing global health care models and proposals for health care reform in the social protection system of Uzbekistan.
\end{abstract}

Keywords: Health insurance, health care, medical services, state budget funds.

\section{INTRODUCTION}

The world has a great deal of experience in the development and optimization of health care financing models in social protection. Developed countries are making wise use of the health insurance system in order to expand the coverage of the population with free medical services, sources of funding, methods of distribution of funds, as well as to increase the efficiency and reduce costs in the health sector.

\section{RELEVANCE OF THE RESEARCH TOPIC}

The current health models in the world are not universal, in this regard, the strengths and weaknesses of the models, the analysis of the experience of foreign countries in this area play an important role in reforming and optimizing health in the social protection system of Uzbekistan.

The purpose of the study. Development of scientific proposals and practical recommendations for the use of foreign experience in health insurance reform in the formation of the health insurance system in Uzbekistan.

Research methods. The research process used grouping, abstract-logical thinking and comparative analysis.

The main results. All models of health care systems in the world can be divided into three types:

1. Budget model (government system)

2. Insurance model (social insurance system)

3. Private model (non-state or market system).

A characteristic feature of the first model, known as the Beveridge model, is that the state takes the lead in this model. The main source of funding is tax revenues. Medical services are provided free of charge for the entire population. Typically, the share of health expenditures in GDP is 8-11 percent. Private insurance and surcharges play an important role.

The main source of funding is the state budget, where health workers receive budget funds under the control of private management companies. The government plays the role of both a provider and a 
user of medical services, providing the majority of health expenditures (more than $70 \%$ ). Health system management is centralized. Most medical services are provided by public health facilities and private physicians, and private medical facilities are given a secondary place.

The second model, known as the Bismarck model, is often defined as a regulated health insurance system. This model is based on the principles of a mixed economy, combined with an advanced system of state regulation of the market of medical services, social guarantees. When statefunded insurance funds, compulsory health insurance programs cover the entire population and the state covers more than 70 percent of health care costs, and government spending on health care is higher than the budget model at 9-13 percent of GDP. Private nonprofits, commercial insurance funds and insurance companies play a crucial role in the distribution of funds. The role of the market in meeting the needs of the population for medical services is great, and patients have the freedom to choose insurance companies and service providers.

The private model of health care deals with the provision of paid services at the expense of private insurance companies and citizens' own funds. The market plays a leading role in meeting the needs for medical services. In practice, the state assumes obligations that are not met by the market, ie covers the costs of providing medical services to citizens in need of social protection (unemployed, lowincome and pensioners).

In the private model, more than 50 percent of funding is provided at the expense of citizens' own private funds. The funds will be collected in private insurance funds and directed to medical institutions. The provision of medical services is decentralized and is carried out by organizations based on different forms of ownership.

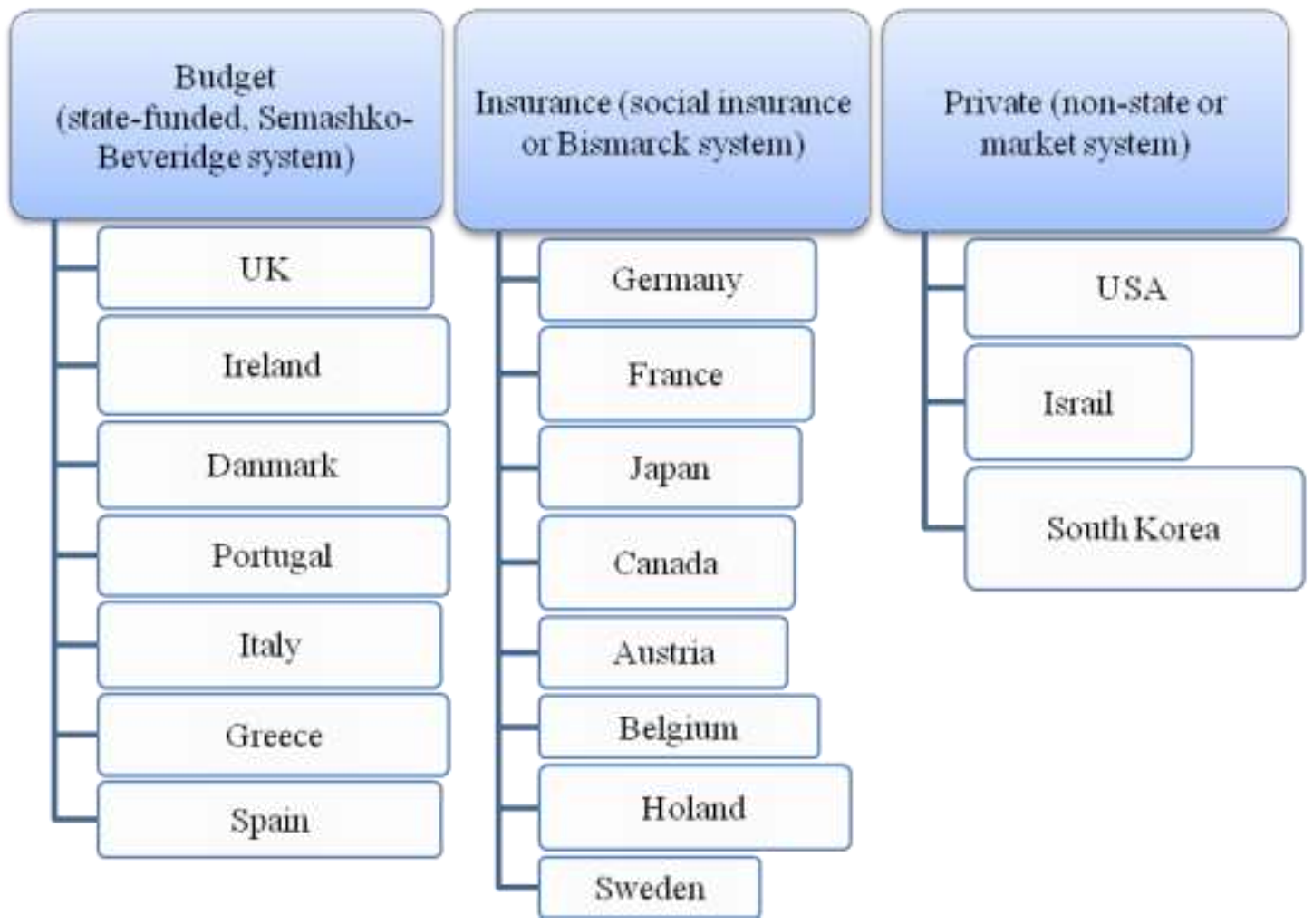




\section{Figure 1. Classification of health care systems in developed countries ${ }^{1}$}

Figure 1 below shows the classification of budget, insurance, and private models of the health care system in developed countries.

On the social protection system - we analyze the experience of the United States, Germany, Great Britain, France and Canada.

Germany is an example of the classic model of social insurance, the sources of funding of which are distributed as follows: social health insurance - 60\%, private health insurance - $10 \%$, the state budget $-15 \%$ and personal funds of citizens - $15 \%$. Almost $90 \%$ of the German population is covered by social health insurance programs and $10 \%$ by private health insurance programs, while $3 \%$ of socially insured people have a voluntary health insurance policy.

In Germany, the share of health expenditures in the country's GDP is $7.8-11.7 \% .75 \%$ of health expenditures are covered from the state budget. The movement of health financing funds had the following appearance, they were first accumulated in the state fund of social health insurance, and then transferred to the accounts of non-profit insurance organizations that control the services of medical institutions. Physicians 'associations, known as hospital funds, form the basis of the social health insurance system. They create self-regulatory structures that manage the provision and financing of legally guaranteed services in compulsory health insurance.

According to the World Health Organization, the incidence of various serious diseases in the country has significantly decreased in the last 2000-2019 due to the widespread use of health insurance in the financing of medical services in Germany. In particular, during the analyzed period, the incidence of ischemic heart disease decreased by 1.6 times, the incidence of vascular disease decreased by 1.7 times (see Figure 2). According to international experts, due to the fact that the population of the country has health insurance policies, along with the expansion of access to health care, the quality of services is improving. As a result, the incidence of serious diseases and premature deaths is declining year by year. ${ }^{2}$

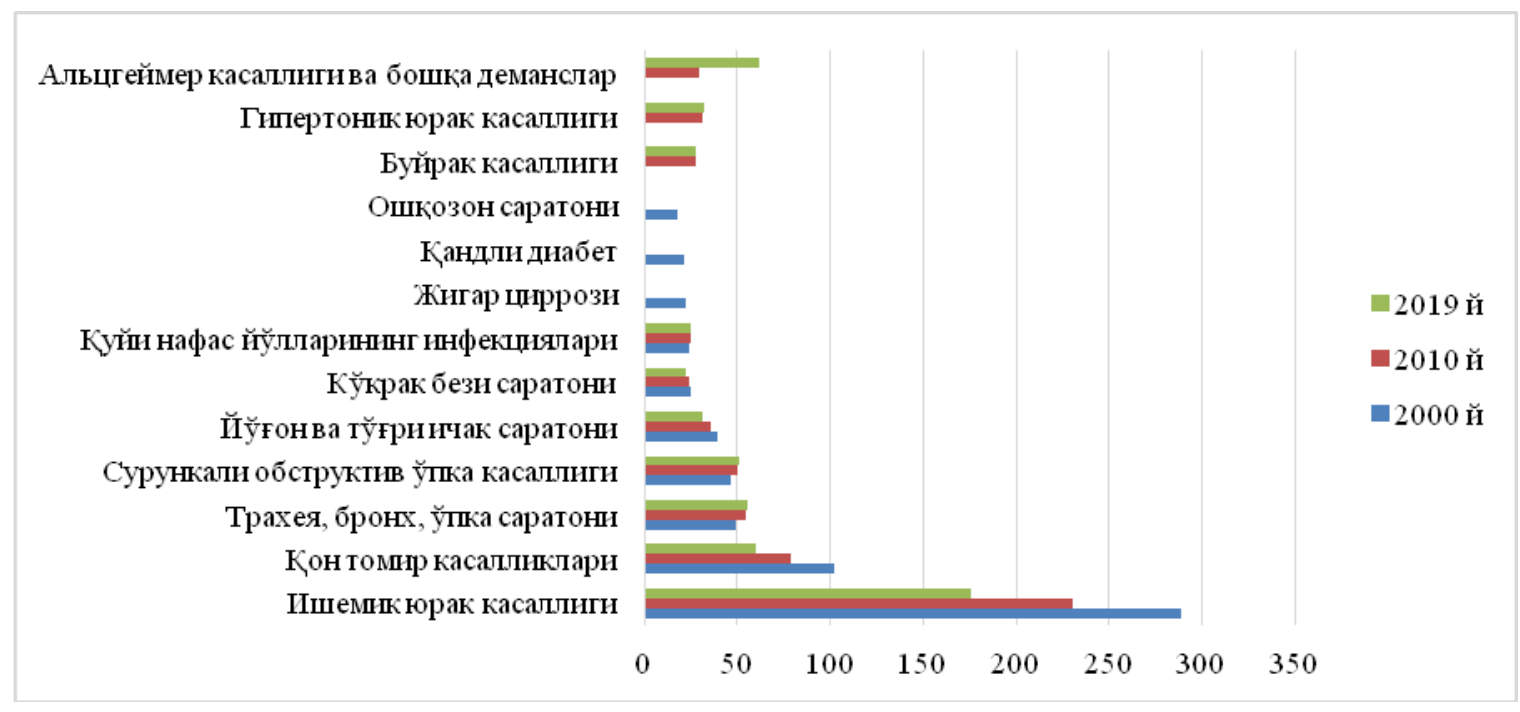

\footnotetext{
${ }^{1}$ Author construction

${ }^{2}$ Global Health Estimates 2020: Deaths by Cause, Age, Sex, by Country and by Region, 2000-2019. World Health Organization. https://www.who.int/data/gho/data/themes/mortality-and-global-health-estimates
} 
In Germany, from 2010 to 2014, the population's desire to use health insurance services increased significantly. As a result, during the period under review, the income of insurance funds began to increase. Due to the demographic aging problem in the country and the spread of new types of diseases, deaths, morbidity and various acquired disabilities, in 2010-2019 the share of insurance funds in the country to meet their obligations increased, and in 2017 the country's health insurance "Zinszusatzreserve ( ZZZ) "method was put into practice. Using this method, a reduction in the cost of insurance funds was achieved (see Figure 3). This method consisted of making changes to the order of payment of various benefits and payments in the event of death.

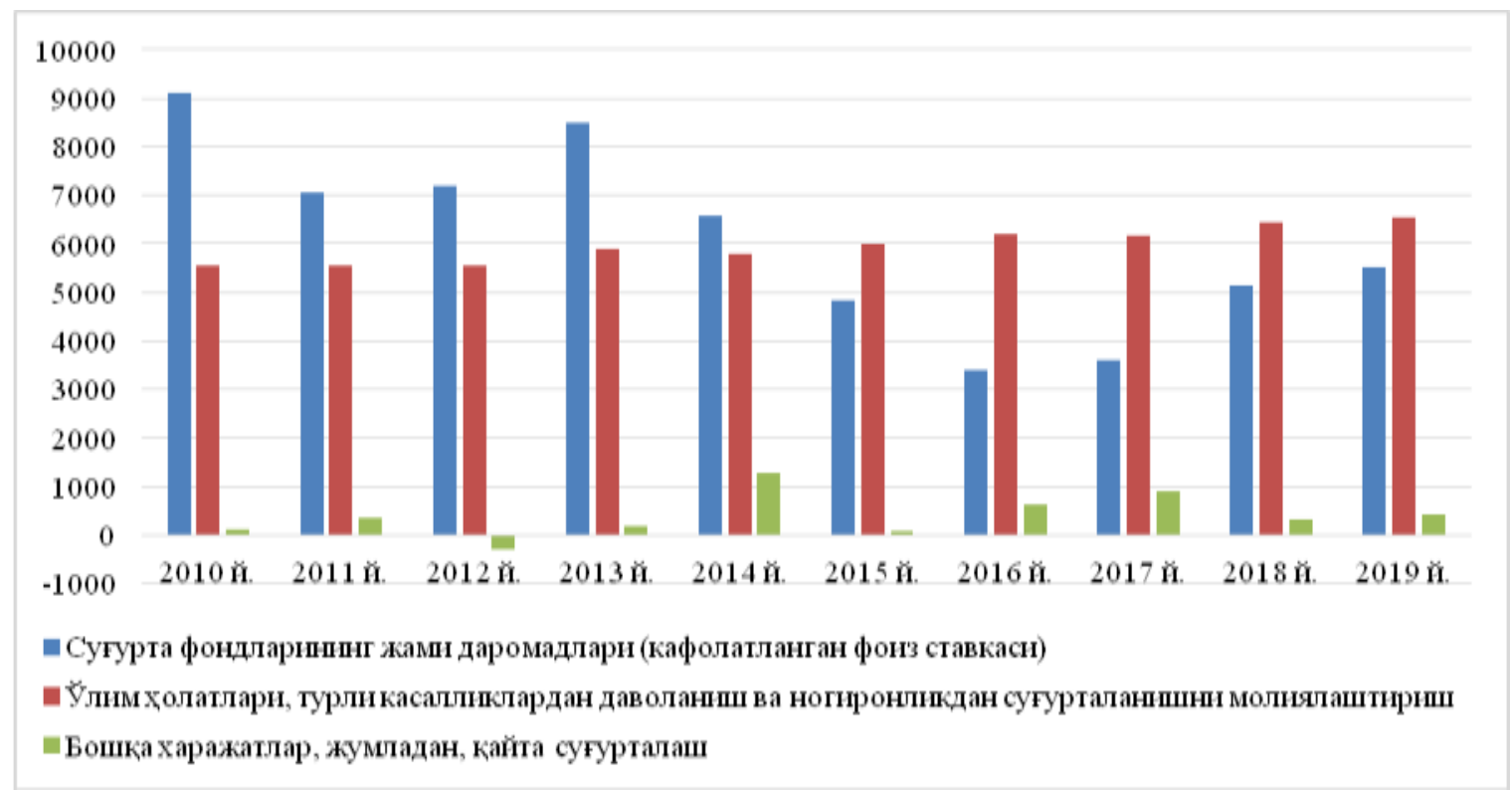

Figure 3. Development trends of the German health insurance market (in million euros). ${ }^{4}$

In the UK budget model, $85 \%$ of health care costs are covered by the state budget, and $15 \%$ are covered by private health insurance. The funds are accumulated in the state budget, and transferred to self-regulatory organizations that manage the financing of treatment and prevention facilities. The form of centralized health management applies. Total government spending is $9.4 \%$ of GDP, of which $7.7 \%$ of GDP is spent on health. The population is covered by free medical services and there are almost no additional fees for medical services. For the able-bodied segment of the population, a fixed fee of $£ 7.85$ per prescription applies.

The state deals with the accreditation of doctors and medical preventive institutions, regulating the activities of doctors. Levels and prices of medical services are managed by trust funds for primary health care. There are currently 152 primary health care trust funds in the UK, which control $80 \%$ of the national health care budget. There are also 167 hospitals and 129 fund trusts in the UK, which provide the bulk of inpatient care in the UK. The United Kingdom has independent local health care systems in

\footnotetext{
3 Compiled by the author based on data from the World Health Organization https://www.who.int/data/gho/data/themes/mortality-and-global-health-estimates/ghe-leading-causes-of-death 4 Compiled by the faculty based on data from the German Federal Financial Services Agency. https://www.bafin.de/EN/PublikationenDaten/Datenbanken/Datenbanken_node_en.html
} 
Scotland, Wales and Northern Ireland. 5 .

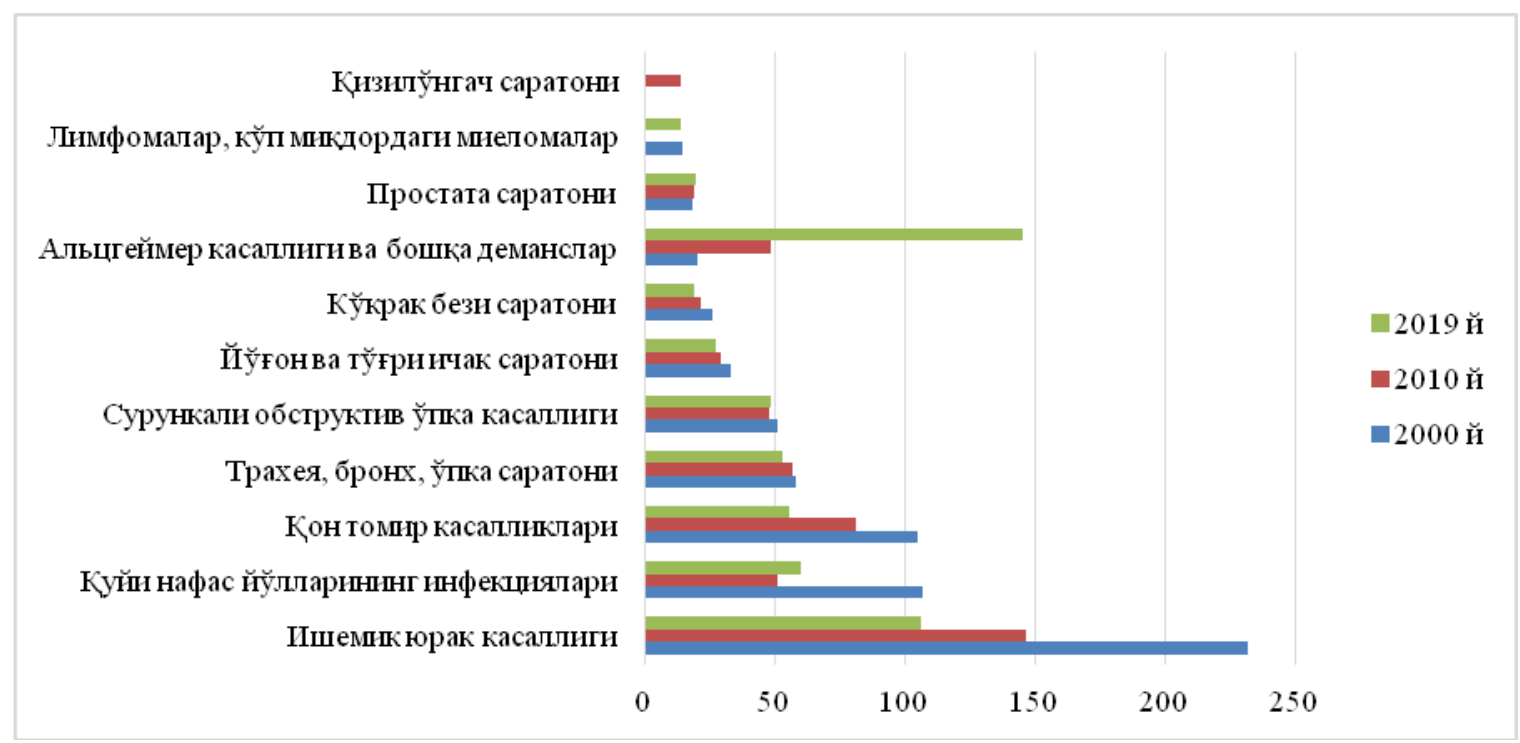

Figure 4. List of TOP-10 diseases that cause death in the UK (per 100,000 population) ${ }^{6}$

According to international experts, in the practice of financing the health care system in the UK, along with health insurance services, the establishment of trust funds provides an opportunity to increase the coverage of medical services to the population. As a result, between 2000 and 2019, the country achieved a reduction in morbidity and mortality from various serious diseases. In particular, the incidence of ischemic heart disease, which is the leading cause of death in the study period, decreased by about 2.2 times, vascular diseases - by 1.9 times, and the incidence of lower respiratory tract infections - by 1.8 times (see Figure 4 ).

In the United States, there is a private model of health care, and there is no national system that covers the entire population. The U.S. is the only developed country where state guarantees in the field of health care apply only to a limited range of citizens and where access to health care is partially available. The leading source of funding is private insurance, which covers more than $50 \%$ of the cost of medical services. Other sources include programs for the elderly and low-income citizens, as well as personal funds of citizens. Management of funding for treatment and prevention facilities and private physicians remains in the hands of private health insurance companies. The state manages the distribution of resources through special government programs for citizens in need of social protection. The management of the national health system is decentralized. The share of total government expenditures in GDP is $17.2 \%$, of which health expenditures from social sources account for $9.1 \%$ of GDP. Provision of access to medical services is limited by patients 'ability to pay. Social programs for the elderly and the poor do not apply to the socially vulnerable and almost do not cover the medical services needed. Nearly 50 million people receive no medical care at all.

In U.S. practice, the implementation of health insurance programs and the increase in the

\footnotetext{
${ }^{5}$ Kullman D. PHIS Pharma Profile United Kingdom (http://whocc.goeg.at/Literaturliste/Dokumente/ CountryInformationReports/PHIS\%20Pharma\%20Profile\%20UK\%20Feb2011.pdf).

6 Compiled by the author based on data from the World Health Organization https://www.who.int/data/gho/data/themes/mortality-and-global-health-estimates/ghe-leading-causes-of-death
} 
coverage of medical services to the population, as well as the prevention of the occurrence of certain types of life-threatening diseases. In particular, between 2000 and 2019, the number of deaths due to ischemic heart disease in the country decreased by 1.4 times, vascular diseases by 1.3 times, and deaths from lung cancer by 1.2 times. It also completely prevented the occurrence of deaths due to lower respiratory tract infections and breast cancer (see Figure 5). ${ }^{7}$

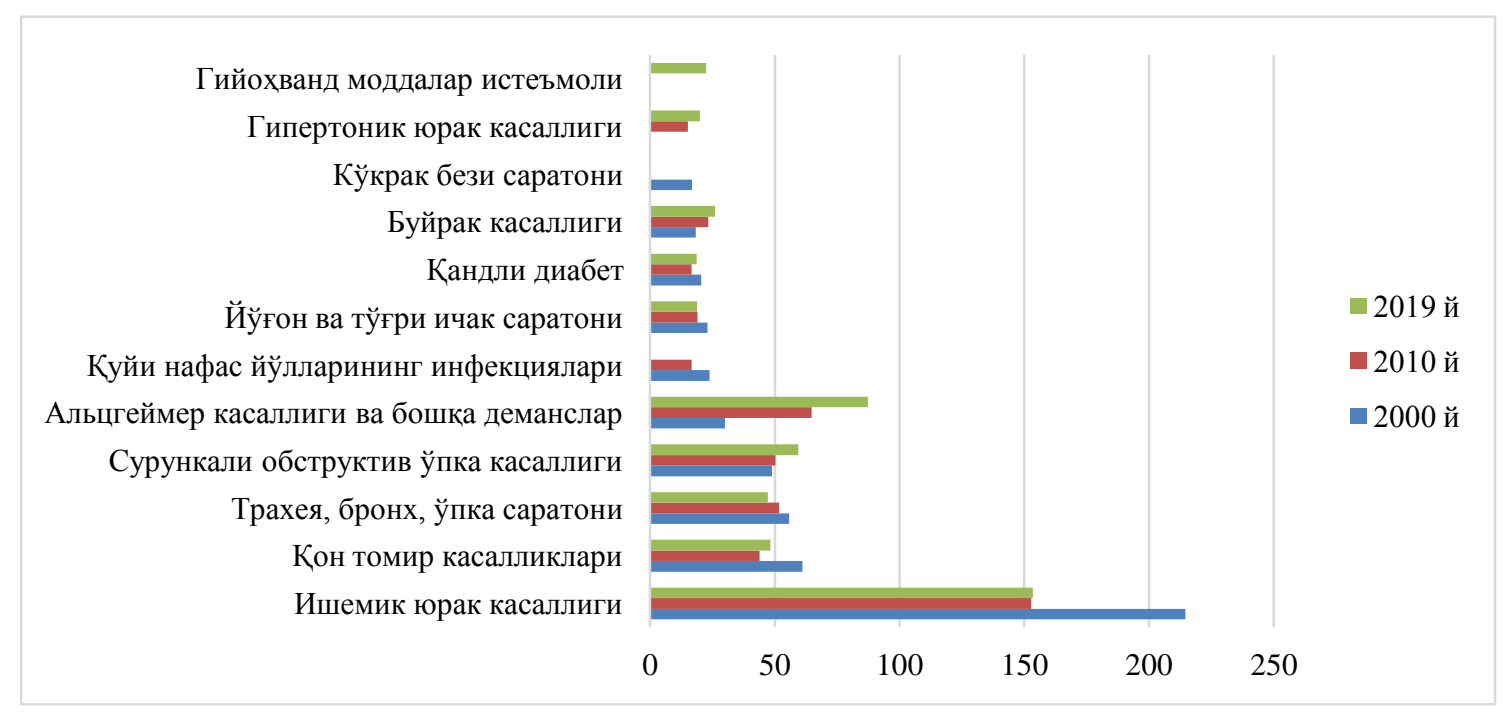

Figure 5. List of TOP-10 diseases that cause death in the United States (per 100,000 population $)^{8}$

Analyzes show that the total amount allocated to health care varies from country to country. The fact that the life expectancy of the population and other health indicators are not proportional to the amount spent, which, firstly, shows the differences in the efficiency of spending, and secondly, shows that other factors affect the life expectancy of the population. It can be observed in the example of life expectancy and expenditure of the population in developed countries analyzed in Table 1.

Table 1

The effectiveness of the cost-benefit ratio in the health system ${ }^{9}$

\begin{tabular}{|l|c|c|c|}
\hline \multicolumn{1}{|c|}{ Country } & Life expectancy & $\begin{array}{c}\text { Share of health expenditures in } \\
\text { the country's GDP\% }\end{array}$ & $\begin{array}{c}\text { Health expenditures per } \\
\text { capita, (in U.S. dollars) }\end{array}$ \\
\hline United States & 78,6 & 17,2 & 8608 \\
\hline Germany & 80,7 & 11,7 & 4875 \\
\hline United Kingdom & 80,8 & 9,4 & 3609 \\
\hline France & 81,7 & 12,5 & 4952 \\
\hline Канада & 80,9 & 10,8 & 5630 \\
\hline
\end{tabular}

\footnotetext{
7 Global Health Estimates 2020: Deaths by Cause, Age, Sex, by Country and by Region, 2000-2019. World Health Organization. https://www.who.int/data/gho/data/themes/mortality-and-global-health-estimates

8 Compiled by the author based on data from the World Health Organization https://www.who.int/data/gho/data/themes/mortality-and-global-health-estimates/ghe-leading-causes-of-death ${ }^{9}$ Most Efficient Health Care: Countries / Bloomberg Visual Data (http://www.bloomberg.com/visual-data/ best-and-worst/most-efficient-health-care-countries).
} 
A comparative analysis of the performance of the health care system in the world practice allows to draw the following scientific conclusions about the advantages and disadvantages of health models (see Table 2):

- countries do not use only one model of social protection and there is no universal model;

- All models of health care have a leading source of funding;

- The state provides more than $70 \%$ of the costs of the budget and insurance models;

- An important factor in ensuring the sustainability of the health care system is the coverage of the population with free medical services, resource efficiency and access to health services.

- The development of the health care system in the country is impossible without insurance payments without the state budget.

In world practice, health insurance is compulsory for employees, in developed countries, compulsory health insurance is the financial basis of the health care system.

The organization of the global health insurance system is well developed, and the leading source of funding for the health care system is health insurance funds. Government and insurance companies are actively involved in this process. Each country is financed from the state budget and health expenditures through compulsory health insurance.

Table 2

\section{Comparative Analysis of the Compulsory Health Insurance System (2018) ${ }^{10}$}

\begin{tabular}{|c|c|c|c|c|c|c|}
\hline \multirow[b]{2}{*}{ Country } & \multicolumn{2}{|c|}{ Health care costs } & \multirow{2}{*}{\begin{tabular}{|c|} 
Compulsory \\
health \\
insurance \\
coverage of \\
the \\
population, \\
(in \%))
\end{tabular}} & \multirow[b]{2}{*}{$\begin{array}{l}\text { Insurers in the } \\
\text { compulsory } \\
\text { health } \\
\text { insurance } \\
\text { system }\end{array}$} & \multirow[b]{2}{*}{$\begin{array}{c}\text { Insurance } \\
\text { premiums } \\
\text { paid from } \\
\text { the salary } \\
\text { fund, (in \%) }\end{array}$} & \multirow{2}{*}{$\begin{array}{c}\text { Distribution } \\
\text { of insurance } \\
\text { premiums } \\
\text { between } \\
\text { employers } \\
\text { and workers, } \\
\text { (in \%)) }\end{array}$} \\
\hline & $\begin{array}{c}\text { Percentage } \\
\text { to GDP } \\
(\text { in } \%))\end{array}$ & $\begin{array}{c}\text { Per capita } \\
\text { expenditures, } \\
\text { (USD)) }\end{array}$ & & & & \\
\hline Germany & 11,3 & 5410,63 & 92 & $\begin{array}{l}\text { Hospital cash } \\
\text { registers }\end{array}$ & $9-15$ & $50 / 50$ \\
\hline USA & 17,1 & 9402,54 & 90 & $\begin{array}{l}\text { Insurance } \\
\text { companies }\end{array}$ & $3-9,5$ & $\begin{array}{l}\text { Depending on } \\
\text { the workplace }\end{array}$ \\
\hline France & 11,5 & 4958,99 & 80 & State & 13,6 & $66 / 34$ \\
\hline
\end{tabular}

The World Health Organization has published the "International Health Rankings" for 2020 by regions of the world. In calculating the results of this rating, the organization's experts made an assessment

\footnotetext{
${ }^{10} \mathrm{http} / / /$ ifmr.uz/возможности-и-перспективы-развития-м/.
} 
of 100 points and used the following system of 13 indicators: ${ }^{11}$

- Legal framework of the health care system and the practice of financing medical services;

- coordination and centralization of medical services;

- food security;

- condition and level of development of laboratory rooms of medical service institutions;

- Cases of zoonotic diseases (infectious diseases of animals);

- control over the quality and scope of medical services;

- The level of staffing of the health system and their potential;

- the level of emergency preparedness of the health care system and medical institutions;

- types of medical services provided to the population and their quality;

- prevention of the spread of infectious diseases;

- The level of incidence of new diseases;

- The impact of chemical phenomena on natural and environmental processes;

- level of preparedness for radionuclide emergencies.

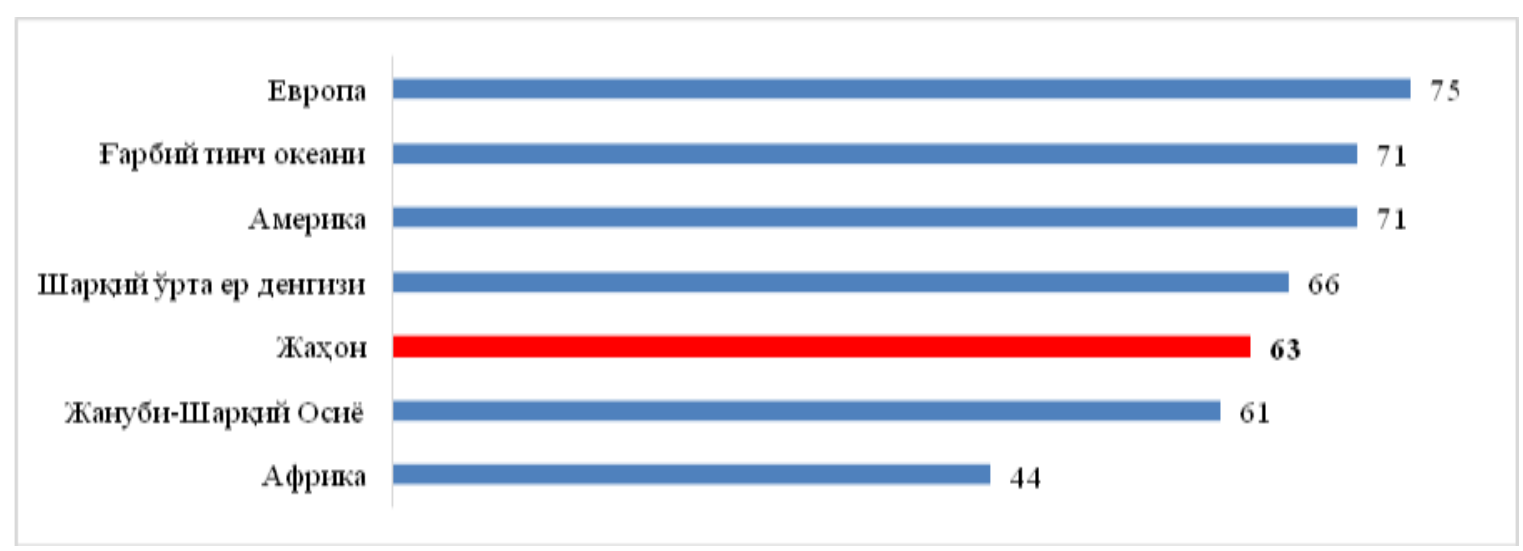

Figure 6. Health System Rating by Region of the World, 2019. ${ }^{12}$

Based on the above indicators, according to a study conducted by experts from the World Health Organization, in 2019 the ranking of the global health system was 63. In the regions of Africa (44) and

Southeast Asia (61), this figure was lower than the world average (see Figure 6).

Due to the widespread use of health insurance in the provision of health services in most EU countries, the legal framework for health system rankings and health care financing practices in the region (80), coordination and centralization of health care (82), quality and scope of health care. components such as control (79), types of medical services provided to the population and their quality (79) are high (see Table 3). It should be noted that the rating on the American continent is averaged for South and North America, while the regional index is relatively lower than the European Union. However, health insurance services in this region are also considered to have been introduced voluntarily in the United States and Canada.

Conclusions and suggestions. It is important to make a comparative analysis of the rich experience of development of the health insurance system in the system of social protection in foreign countries, to

\footnotetext{
${ }^{11}$ Based on data from the World Health Organization https://www.who.int/data/gho/whs-2020-visual-summary

12 Compiled by the author based on data from the World Health Organization https://www.who.int/data/gho/whs-2020visual-summary
} 
study the issues of social protection of the population in Uzbekistan, the creative application of health insurance in the health system. The study of the accumulated rich, advanced foreign experience in the health system will allow to identify priorities for the development of the local health system. Foreign experience shows that in countries with a high level of state participation in the medical sector, they often improve the quality of medical care and increase life expectancy.

At the same time, the private sector should be developed, taking into account the level of income of the population, the demographic situation and the availability of financing for the health insurance system. A minimum list of medical services that everyone has access to, regardless of their financial or legal status in the community, should be guaranteed.

Table 3

Global Health System Rating and its components ${ }^{13}$

\begin{tabular}{|c|c|c|c|c|c|c|c|}
\hline & 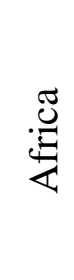 & 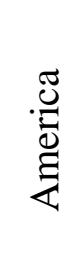 & 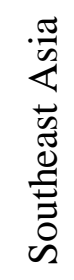 & 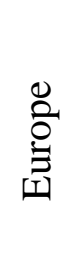 & 离 & 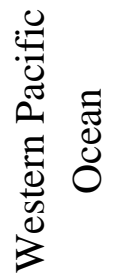 & $\sum_{\bar{Z}}^{\circ}$ \\
\hline $\begin{array}{l}\text { Legal framework of the health care system } \\
\text { and the practice of financing medical } \\
\text { services }\end{array}$ & 43 & 74 & 67 & 80 & 64 & 76 & 65 \\
\hline $\begin{array}{l}\text { Coordination and centralization of medical } \\
\text { services }\end{array}$ & 51 & 78 & 69 & 82 & 74 & 72 & 70 \\
\hline $\begin{array}{l}\text { Cases of zoonotic diseases (infectious } \\
\text { diseases of animals) }\end{array}$ & 50 & 72 & 58 & 80 & 77 & 65 & 67 \\
\hline Food security & 43 & 78 & 53 & 77 & 64 & 75 & 64 \\
\hline $\begin{array}{l}\text { Condition and level of development of } \\
\text { laboratory rooms of medical service } \\
\text { institutions }\end{array}$ & 56 & 79 & 73 & 81 & 69 & 81 & 72 \\
\hline $\begin{array}{l}\text { Controlling the quality and scope of } \\
\text { medical care }\end{array}$ & 61 & 78 & 78 & 79 & 72 & 84 & 73 \\
\hline $\begin{array}{l}\text { The level of staffing of the health system } \\
\text { and their potential }\end{array}$ & 49 & 70 & 60 & 71 & 64 & 68 & 63 \\
\hline $\begin{array}{l}\text { The level of emergency preparedness of } \\
\text { the health care system and medical } \\
\text { institutions }\end{array}$ & 40 & 73 & 58 & 73 & 65 & 75 & 62 \\
\hline $\begin{array}{l}\text { Types of medical services provided to the } \\
\text { population and their quality }\end{array}$ & 41 & 64 & 61 & 79 & 68 & 70 & 62 \\
\hline Prevent the spread of infectious diseases & 43 & 68 & 71 & 66 & 60 & 69 & 60 \\
\hline The level of incidence of new types of & 36 & 70 & 53 & 60 & 64 & 70 & 56 \\
\hline
\end{tabular}

${ }^{13}$ Compiled by the author based on data from the World Health Organization https://www.who.int/data/gho/whs-2020visual-summary 


\begin{tabular}{|l|c|c|c|c|c|c|c|}
\hline diseases & & & & & & & \\
\hline $\begin{array}{l}\text { Influence of chemical phenomena on } \\
\text { natural-ecological processes }\end{array}$ & 32 & 60 & 45 & 69 & 56 & 70 & $\mathbf{5 4}$ \\
\hline $\begin{array}{l}\text { Радионуклеар фавқулодда вазиятларга } \\
\text { тайёргарлик даражаси }\end{array}$ & 32 & 59 & 45 & 77 & 57 & 54 & $\mathbf{5 5}$ \\
\hline \multicolumn{1}{|c|}{ Health system rating } & $\mathbf{4 4}$ & $\mathbf{7 1}$ & $\mathbf{6 1}$ & $\mathbf{7 5}$ & $\mathbf{6 6}$ & $\mathbf{7 1}$ & $\mathbf{6 3}$ \\
\hline
\end{tabular}

\section{Reference}

1. Omelyanovskiy V.V. and other Foreign experience: models of financing and organization of health systems. Financial journal / Financial journal №3 2014. - P. 23.

2. Most Efficient Health Care: Countries / Bloomberg Visual Data 2013 (http://www.bloomberg.com/visual-data/best-and-worst/most-efficient-health-carecountries).

3. https://www.who.int/data/gho/data/themes/mortality-and-global-health-estimates/gheleading-causes-of-death

4. Global Health Estimates 2020: Deaths by Cause, Age, Sex, by Country and by Region, 2000-2019. World Health

Organization. https://www.who.int/data/gho/data/themes/mortality-and-global-health-estimates

5. https://www.who.int/data/gho/data/themes/mortality-and-global-health-estimates/gheleading-causes-of-death

6. https://www.bafin.de/EN/PublikationenDaten/Datenbanken/Datenbanken_node_en.html
7. Kullman
D. PHIS
Pharma
Profile
United
Kingdom (http://whocc.goeg.at/Literaturliste/Dokumente/CountryInformationReports/PHIS\%20Phar ma\%20Profile\%20UK\%20Feb2011.pdf

8. Most Efficient Health Care: Countries / Bloomberg Visual Data (http://www.bloomberg.com/visual-data/best-and-worst/most-efficient-health-carecountries).

9. http://ifmr.uz/возможности-и-перспективы-развития-м/.

10. https://www.who.int/data/gho/whs-2020-visual-summary 